\title{
Teachers' Perceptions of Gratitude in Classroom Interactions: A Case Study from Finland
}

\author{
Leonardo Cedillo Berber ${ }^{*}$ \\ University of Helsinki \\ Helsinki, Finland \\ Elina Kuusisto \\ University of Humanistic Studies \\ Utrecht, The Netherlands/ \\ University of Tallinn \\ Tallinn, Estonia \\ Kirsi Tirri \\ University of Helsinki \\ Helsinki, Finland
}

\begin{abstract}
Over the past two decades, gratitude as a scientific topic has been growing in interest. Little is known about its importance in educational environments and classroom interactions. The present article offers an account of a qualitative study that identifies gratitude as a moral value and uses stimulated recall methodology to explore the experience of gratitude in a school environment. Two first-grade teachers from an urban area of Finland were recorded during normal lessons. Deductive and inductive content analyses of a total of 26 critical incidents were conducted to explore expressions of gratitude and the reasons for them. The data shows that teacher-student relationships, material benefits, class routines and self-sufficiency are reasons to experience gratitude. Also, verbal, concrete and connective expressions of gratitude in classroom interactions were identified. The study contributes to the sparse knowledge about gratitude in school environments and provides important insights for understanding the phenomenon in this specific context.
\end{abstract}

Keywords: Gratitude; classroom interactions; stimulated recall.

*Corresponding author: Leonardo Cedillo Berber, leonardo.cedilloberber@helsinki.fi 


\section{Introduction}

\subsection{Gratitude as a concept}

As gratitude has developed as a research topic in different academic areas, it is necessary to acknowledge its complexity and provide insights that will help in its understanding and usefulness in different contexts in everyday life. This article addresses the topic by exploring how gratitude is experienced and expressed in classroom environments. First, gratitude is considered theoretically in the context of morality; then, it is explored in classroom interactions; finally, some features of the Finnish context are analysed as a means of coming to an understanding of this concept.

As a scientific topic, gratitude has been gaining attention in the psychological field over the last eighteen years (Gulliford, Morgan, \& Kristjánsson, 2013). However, historically, its study has been part of important theological and philosophical debates about human life (Harpham, 2004; Wood, Maltby, Stewart, \& Stephen, 2008). Moreover, gratitude has been linked to diverse conceptual contexts, such as emotions, morality (Emmons, 2004), attitudes and traits (Gordon, Musher-Eizenman, Holub, \& Dalrymple, 2004; Howells, 2014).

In the context of morality, gratitude is conceived of as part of several moral operations or devices that societies have developed to facilitate social exchanges between individuals, whether in kinship or not. These exchanges in turn help to preserve societies and their values over time by preventing individuals from acting destructively towards each other (Freitas, Pieta, \& Tudge, 2011; Piaget, 1995). In this light, gratitude is experienced when:

"Person A (the beneficiary) receives a benefit (a present, favour, or help) from Person $B$ (the benefactor) and, recognizing that Person B acted in order to meet a need or desire of Person A, Person A feels positive towards $B$ in return. As a result of the positive feeling associated with Person B, Person A also wishes to repay B in some way if an opportunity arises."

(Nelson et al., 2013, p. 43).

In a similar way, gratitude can also be considered a virtue when it is defined as a reliable and persistent disposition to act in a virtuous manner, an asset developed when an individual reflects on how to think, feel and act virtuously (Tudge, Freitas, \& O'Brien, 2015). This reflective act, in turn, is influenced by the individual's worldviews, which have been described as broad and personal interpretations of life (van der Kooij, de Ruyter, \& Miedema, 2013). Worldviews are defined as views and beliefs about humanity, life, the world, social relationships, and the underlying nature of reality, just to mention some of the features (van der Kooij et al., 2013; Koltko-Rivera, 2004). It is thus understood that gratitude is related to a person's worldview.

In what can be considered the first scientific work on gratitude, BaumgartenTramer (1938) identified verbal, concrete, connective and finalistic aspects of this phenomenon. Verbal gratitude, identified as a "thank you" reply, can be understood as what parents have taught their children. On the one hand, this 
might not necessarily denote a grateful feeling; on the other hand, it might be related to an overwhelming feeling expressed verbally (Baumgarten-Tramer, 1938; Freitas et al., 2011). Concrete gratitude occurs when a person wants to repay a benefit received with an object, whether or not it is valuable to the benefactor. Connective gratitude is a more equal process which arises whenever the receiver creates or attempts to "create a spiritual relationship with the donor" (Baumgarten-Tramer, 1938, p. 61). And finalistic gratitude is the "tendency to reciprocate for the realization of his wish by an action which would be in some way helpful for the object or the situation desired, or would promote their personal development" (Baumgarten-Tramer, 1938, p. 62). In other words, finalistic gratitude connects future activities with the beneficiary's desire.

Baumgarten-Tramer's study (1938) analysed the responses of 1,059 children aged seven to fifteen from elementary grades to secondary school using the questions: "What is your greatest wish?" and "What would you do for the person who granted you this wish?" The results showed that verbal gratitude was found equally among children of various ages, with 30 to 48 percent of the pupils expressing gratefulness. Concrete gratitude was most frequent among 8year olds $(51 \%)$. Connective gratitude was reported to be more frequent when children turned age 11. No statistical accounts were reported for the finalistic type of gratitude. These outcomes are supported in a recent study by Freitas et al., (2011). Their results showed similar tendencies; however, these authors added a category called self-sufficiency, which involves responses when individuals recognise that they "should obtain what he or she desires by him- or herself" (p. 761).

The above results raise important questions about how gratitude emerges in the course of children's development. Although to date little is known about gratitude as a developmental issue (Bono \& Froh, 2009), an inter-individual perspective seems to provide strong arguments for its understanding. Unlike the Innatist view held by Klein (1988), gratitude is a process evolving over several years (Emmons \& Shelton, 2005) and develops during childhood and adolescence (Baumgarten-Tramer, 1938). It is a product of environmental factors that involve a child interacting with individuals, consistently participating in a certain environment with continuous effort and focusing on feeling gratitude (Bono \& Froh 2009; Freitas et al., 2011). Meanwhile, adults provide the children with assistance related to the understanding of emotions by facilitating activities and discussions that include insights about social situations in which receiving help or a gift is involved (Bono \& Froh, 2009).

Up to the present time, it has been thought that gratitude may begin as early as the age of five (Nelson et al., 2013), and its assessment is possible with different scales. Research has found that emotional knowledge and understanding the mental states of others are important factors underpinning the development of gratitude as a notion that associates receiving a benefit with positive feelings specific to the benefactor (Nelson et al., 2013). This first notion of gratitude seems to be expressed with and caused by material objects; later, as children grow older, their experiences of gratitude are related more to the value of interpersonal relationships (Freitas et al., 2011; Gordon et al. 2004). Some of the 
scales that have been used are the Gratitude-Questionnaire-6 (GQ6); the Gratitude, Resentment, Appreciation Test (GRAT) (Gulliford et al., 2013); and the Multi-Component Gratitude Measurement (MCGM, Morgan, Gulliford, \& Kristjánsson, 2017).

Despite the recent interest in gratitude, in an educational context the term still needs precise definition (Gulliford et al., 2013). Gratitude in education has not yet been studied with regard to its origin, whether personal or impersonal, but it seems to use the same conceptual frameworks mentioned at the beginning of this introduction. Gratitude is also associated with other positive and negative emotional states, such as happiness, hope, and indebtedness (Gulliford et al., 2013). Nevertheless, understandings of beneficiary and benefactor differ, owing to the complexity of the whole educational phenomenon (Gulliford et al., 2013; Howells, 2014; White, 1999). Among other things, this complexity involves the sharing of practices, values, rules and beliefs throughout a culture across time and generations (Tudge, 2008). In the case of gratitude, this sharing might start with teachers who typically encourage expressions of gratitude that are regular as well as public (McAdams \& Bauer, 2004). The role of teachers in supporting gratitude seems to be crucial, for they help "in creating conducive classroom environments that relate to students' positive interactions ..." with others (Liauw, Baelen, Borah, Yu, \& Colby, 2018, p. 400). Individuals explicitly remember being taught to be grateful for certain gifts, benefits, services or actions from which they have benefitted (Eisenstein \& Bodman, 1993), especially when bestowed by adults (McAdams \& Bauer, 2004).

Few studies have focused on the meaning of gratitude and its experience in primary and secondary school settings. For Howells (2014; Howells \& Cumming, 2012), gratitude is an active and conscious action, and not merely appreciation, whereby individuals act on their grateful feelings in ways such as greeting and thanking students or colleagues. Howells' (2014) study of gratitude in secondary schools revealed that teachers may conceptualize gratitude as a direct action, an emotional state and/or a social interaction. Moreover, in an earlier study, Howells and Cumming (2012) reported that their participants related the effects of gratitude on their well-being, such as increasing resilience and generating more positive feelings and less negative ones. This helps to demonstrate that gratitude in education has its own meaning. Gratitude in classroom environments has also begun to be recognized for its own sake; it seems to be an interactive and dynamic process with the potential to add important elements to the contemporary debate about this concept both in and outside classroom environments.

\subsection{The Finnish context}

In Finland, the goal of education is to support the holistic development of diverse learners rather than address only the cognitive domain (Finnish National Board of Education , 2016; Tirri, 2011). This kind of education acknowledges the importance of social, affective, moral and spiritual development of the students. The Finnish educational system has adapted features from both German and Anglo-American traditions; for example, the German didactic models, with their 
strong emphases on values and morals, have been followed. In the Finnish curriculum, values guide the teacher in the teaching-studying-learning process in classrooms. This makes education normative in nature and has implications for the teacher's role as a moral educator. Every teacher is a moral educator regardless of the subject matter taught. The ethical role of a teacher has changed during the last 40 years from that of a religious and moral example to a principled professional who needs moral competence in pedagogical encounters (Tirri, 2014).

Education is also seen as context-dependent. Context-dependency means that the teaching-studying-learning process is intentional, that actions are based on values and purposes, and that the process is located in some institution in the society. Furthermore, teachers are involved as professionals in institutional teacher education, and it is assumed that the outcomes of studying, with learning as the most important part, are achieved within the framework of a systematic curriculum (Tirri, 2016).

In the Finnish context, professional ethical codes for teachers clarify their roles and relationships in teaching-studying-learning process (Trade Union of Education in Finland, 2010; Tirri, 2010). We know from earlier studies that Finnish teachers value professional commitment in terms of caring and cooperation in critical situations in their work (Hanhimäki \& Tirri, 2009). In these incidents Finnish teachers consider both personal values and the ethical standards of their profession. They reflect on their own values and virtues as a teacher. We know that teachers cannot separate their own moral character from their professional selves. Their own moral character functions as a moral approach in reasoning, guiding their interactions with their pupils and their families. The professional character includes rules and principles guiding their pedagogical practice and decision-making. These rules and principles build teachers' professional character in practical knowing (Tirri, Husu, \& Kansanen, 1999).

The purpose of this article is to explore gratitude in a school environment in a specific society, namely Finland. This exploration aims to provide better understanding of gratitude in classroom environments from teacher's viewpoint. It is also intended to contribute to a solid definition of the concept by examining incidents in which gratitude is experienced in classroom situations and identifying its causes and expressions. With these aims, the study highlights the importance of recognizing possible gratitude events in classroom environments and provides support for individuals experiencing gratitude. The framework is a case study of two Finnish first-grade teachers. The research questions are:

What are teachers' perceptions of the reasons for gratitude in classroom contexts?

How is gratitude expressed in primary classroom contexts? 


\section{Data and Methods}

\subsection{Participants}

The study was conducted in a primary school in an urban area of Finland and in a context in which the native language was Finnish, it was decided to contact as many teachers as possible. Had a large number of teachers replied to our initial contact, then selection criteria would have been needed to choose the study participants. As it turned out, of the forty teachers contacted by email, only one person replied. This teacher in turn informed a colleague, who also became interested in the research. As a result, two first-grade primary school teachers from the same school - one male, 'Matti', and one female, 'Anni' - participated in the study. The initial aims were maintained during the gathering of the data; however, the research questions, originally related to the psychological mechanisms of gratitude, were adjusted for the analysis presented in this article. The teachers had nearly the same number of students in their respective classrooms, 20 pupils (10 girls and 10 boys) in Matti's and 19 pupils (11 girls and 8 boys) in Anni's. Most of the students were seven years of age. Matti had twenty-five years of teaching experience and Anni had six. Both were class teachers with a master's degree in education. Regarding gratitude as a concept, they had had different experiences: whereas Matti had read magazine and newspaper articles on gratitude written from a positive psychology perspective, Anni reported having little information about gratitude as a concept.

\subsection{Data gathering}

In this qualitative case study, stimulated recall was used to explore the teachers' perceptions of gratitude in their classrooms. Stimulated recall typically involves the use of some recorded material to help individuals recollect their thoughts and decision-making processes about certain actions they performed in the past (Calderhead, 1981). Although one of the main characteristics of the method is to stimulate cognitive processes (Lyle, 2003), its potential to obtain narrative accounts from participants became more relevant for the study as it progressed.

Data gathering started with preliminary observations in both classrooms. A onehour observation was done with each group. After this, lessons were videotaped for the stimulated recall interviews - Matti's for 48 minutes and Anni's for 52 minutes. Both teachers suggested the time and the length of the recordings based on their workloads. Both lessons were in mathematics and were recorded on the same day. Later the same day, each teacher received a copy of his/her recorded class in mp3 format. Matti and Anni were then asked to identify moments of gratitude (Gass \& Mackey, 2000). These were considered as critical incidents, which were discussed in detail with the teachers during the stimulated recall interviews which took place within five days. The videos were also examined by the researcher and by a Finnish-speaking trained coder in an effort to identify the same types of incidents mentioned in each interview. The stimulated recall interviews were also tape recorded, and the critical incidents as well as the full interviews were transcribed. The data comprise a total of 17,139 words in 57 pages in Times New Roman 12 pt. type font, with spacing at 1.5 
lines in Microsoft Word ${ }^{\circledR}$ text processor. In addition, the researchers kept a journal during the observation and recording phases to clarify events and help them understand the data.

\subsection{Data analysis}

In total, 26 different critical incidents -potential moments of gratitude - were identified. Seventeen of these were identified by the teachers only: seven by Matti and ten by Anni. Each moment had at least one narrative with reasons to be grateful in the classroom and another narrative on how gratitude was expressed; e.g. "Arthur is very happy and grateful [student shows his gratitude by being happy] that now his work is done, and I gave him, and only him, permission to go to the little, ummm, library [the reason the student is grateful]" (Anni, critical moment 15). Some critical incidents provided more than two reasons for the child or teacher to feel grateful; for instance, Anni believed Arthur experienced gratitude when he got her help with a task [reason 1], but also got attention from her [reason 2] (Anni, critical moment 20); and more than one expression related to this feeling; e.g. after being given an eraser, Rachel was reported as feeling grateful. From Anni's viewpoint, this was expressed in the phrase "ok, thank you and now I won't [lose it again], she [Rachel] said." (Anni, critical moment 21). In these cases, as suggested by Freitas et al., (2011), codes derived from these accounts were recorded both when the codes occurred alone and when they occurred in another category.

Because the study focuses on teachers' perceptions of what first graders and teachers are grateful for and how gratitude is expressed in classroom contexts, two different approaches were taken to the content analysis of the critical incidents. For the first question, following the suggestions by Elo and Kyngäs (2008) and Graneheim, Lindgren, and Lundman (2017), an inductive content analysis was used, as gratitude had not yet been deeply studied in the field of education. The names of the four created main categories were based on the data with the exception of the fourth, 'self-sufficiency', which was adapted from Freitas et al. (2011). The main categories, their definitions and examples from the data are presented in Table 1.

For expressions of gratitude, Baumgarten-Tramer's (1938) categories were utilized as a deductive analytical framework. In the course of the analysis, it was found that each critical incident had at least one reference to an expression of gratitude; however, some incidents had double-edged moments. These moments were characterised by potential gratitude experiences by the teacher and one or more pupils and led either to different or to the same types of expression in the same environment. Thus, while one moment could be categorised as verbal based on the child's expression, it could also fit the concrete category because of the teacher's narrative accounts. Teachers' descriptions could include sentences expressed in either past or present tense. Table 2 shows Baumgarten-Tramer's (1938) categories with definitions and examples from the present data. It should be noted that expressions related to Baumgarten-Tramer's finalistic category were not found in the data. 
Table 1. Categories of reasons to be grateful

\begin{tabular}{|c|c|c|}
\hline Category & Definition & $\begin{array}{c}\text { Data examples of reasons to be } \\
\text { grateful }\end{array}$ \\
\hline $\begin{array}{l}\text { Teacher- } \\
\text { student } \\
\text { relationship }\end{array}$ & $\begin{array}{c}\text { Situations where } \\
\text { individuals were given } \\
\text { task-related help, positive } \\
\text { feedback, attention, or were } \\
\text { trusted in order to } \\
\text { accomplish an activity. }\end{array}$ & $\begin{array}{l}\text { Example of task-related help in a teacher- } \\
\text { student relationship: } \\
\text { "I felt that [gratitude] in that moment, } \\
\text { when I said, 'you can also use your own } \\
\text { fingers to do it [a math task]'. It makes } \\
\text { them a bit easier and comfortable" } \\
\text { (Matti, critical incident 14) }\end{array}$ \\
\hline $\begin{array}{l}\text { Material } \\
\text { benefits }\end{array}$ & $\begin{array}{l}\text { Situations in which } \\
\text { individuals received a gift } \\
\text { or were provided with } \\
\text { specific tools to finish a } \\
\text { task. }\end{array}$ & $\begin{array}{l}\text { Teacher [Anni] bows while receiving a } \\
\text { present [paper gift] from Rachel, and } \\
\text { Anni seems surprised by the student's } \\
\text { action. (Anni, critical incident } 25 \text { ) }\end{array}$ \\
\hline $\begin{array}{l}\text { Classroom } \\
\text { organization } \\
\text { and routines }\end{array}$ & $\begin{array}{l}\text { Daily practices involving } \\
\text { situations in which } \\
\text { individuals acknowledge } \\
\text { rules, practices or } \\
\text { expressions as a way to } \\
\text { keep the classroom } \\
\text { structure or sense of } \\
\text { community. }\end{array}$ & $\begin{array}{l}\text { "This is a routine for us. [E]very day } \\
\text { you can shake hands or give a hug or } \\
\text { then you can just say 'bye, bye' [to } \\
\text { thank you for the day's work]". (Anni, } \\
\text { critical incident } 3 \text { ) }\end{array}$ \\
\hline Self-sufficiency & $\begin{array}{l}\text { Teacher's reflection on } \\
\text { his/her past as a teacher } \\
\text { and self-regulation }\end{array}$ & $\begin{array}{l}\text { "II felt gratitude since] I was able to } \\
\text { change my feelings from some } \\
\text { frustration [...] to positive" (Matti, } \\
\text { critical incident } 23 \text { ) }\end{array}$ \\
\hline
\end{tabular}

Table 2. Categories of expressions of gratitude

\begin{tabular}{ccc}
\hline Category & Definition & $\begin{array}{c}\text { Data examples of } \\
\text { expressions of gratitude }\end{array}$ \\
\hline Verbal & It is expressed with the phrase 'thank & $\begin{array}{c}\text { "Oh thank you very much, } \\
\text { we can put it there" (Anni, } \\
\text { critical incident 26) }\end{array}$ \\
\hline Concrete & $\begin{array}{c}\text { Expressions in which individuals reflect } \\
\text { the desire to finish/continue an activity } \\
\text { by asking for help from another person } \\
\text { and, in return for the favour received, } \\
\text { he/she completes the task or other action } \\
\text { denoting satisfaction for his/her effort } \\
\text { during the activity or the class. }\end{array}$ & $\begin{array}{c}\text { "I think that Paula shows } \\
\text { relief and some gratitude } \\
\text { when I'm helping her with } \\
\text { the task" (Anni, critical } \\
\text { incident 19) }\end{array}$ \\
\hline Connective & $\begin{array}{c}\text { Expressions in which the beneficiary is } \\
\text { perceived as creating strong ties with the } \\
\text { benefactor by means of positive } \\
\text { feedback, trust or engagement. }\end{array}$ & $\begin{array}{c}\text { "I felt it was something } \\
\text { between us" (Matti, critical } \\
\text { incident 8) }\end{array}$ \\
&
\end{tabular}




\section{Results}

\subsection{Teachers' Perceptions of Reasons for Gratitude in a School Context}

Of the 26 critical incidents, 34 different accounts of reasons to be grateful in classroom interactions were identified. The majority of cases $(\mathrm{f}=23)$ were identified in the teacher-student relationship category as shown in Table 3 while, in turn, four subcategories were created for this category (hereafter main categories are italicized and in bold, while subcategories are italicized only). According to Matti and Anni, gratitude might be experienced due to task-related help $(\mathrm{f}=8)$. In Anni's classroom, after waiting for some time, a student called Paula showed Anni the task she needed help with. Anni clarified the task and they whispered to each other. The teacher then knelt down and started explaining the task again, using her hands. Anni explained, "I think that Paula shows [...] some kind of gratitude when I'm helping her with the task" (Anni, critical incident 19).

Table 3. Teachers' perceptions of reasons for gratitude in a school context

\begin{tabular}{ccccc}
\hline Main categories & Subcategories & $\begin{array}{c}\text { Student } \\
\mathrm{f}=25\end{array}$ & $\begin{array}{c}\text { Teacher } \\
\mathrm{f}=9\end{array}$ & $\begin{array}{c}\text { In total } \\
\mathrm{f}=34\end{array}$ \\
\hline Teacher-student relationship & Task-related & $\mathbf{2 0}$ & $\mathbf{3}$ & $\mathbf{2 3}$ \\
& $\begin{array}{c}\text { help } \\
\text { Positive } \\
\text { feedback }\end{array}$ & 6 & 1 & 8 \\
& Attention & 5 & 0 & 6 \\
& Trustful & 2 & 0 & 5 \\
& interactions & & 2 & 4 \\
& & $\mathbf{3}$ & $\mathbf{1}$ & $\mathbf{4}$ \\
& & $\mathbf{2}$ & $\mathbf{2}$ & $\mathbf{4}$ \\
Material benefits & & $\mathbf{0}$ & $\mathbf{3}$ & $\mathbf{3}$ \\
\hline
\end{tabular}

The teachers' perception was that gratitude took place in moments when positive feedback $(\mathrm{f}=6)$ was given. During an explanation of a maths exercise in front of the classroom, Matti made a joke related to a math task, when suddenly another student, Alfred, commented, "This is too easy. I know this [...], this is like addition" (Matti, critical moment 6). Matti then replied, addressing the whole group, "Alfred was quite right about that thing he just said" (Matti, critical incident 6). Matti then remarked that his positive feedback had made Alfred grateful and happy.

Gratitude was also perceived when students received attention $(\mathrm{f}=5)$ from the teacher. A student named Sara approached Anni and touched her back with one hand to get her attention (Anni, critical incident 17). Anni explained later, "I noticed her at that moment and I gave her the little bit of attention she needed. [...] She only wants the teacher to give her a little bit of attention and then she can continue". After this encounter, Sara left smiling.

The last subcategory found was trustful interactions ( $\mathrm{f}=4$ ). During the lesson, Matti began telling a story to aid his introduction to a new mathematics topic. 
The story involved counting how many objects were left after he dropped some from a box. Throughout the storytelling, the children seemed to be engaged and they all paid attention and counted enthusiastically until the story was finished. According to Matti, he himself was very grateful for this moment, since he "felt it was something special between us" (Matti, critical incident 8).

A second category of gratitude we identified was material benefits $(\mathrm{f}=4)$, in the form of tools or gifts given when a task was successfully completed or at the end of the lesson. For instance, a case where the student, Rachel, asked Anni whether she might keep the eraser that the teacher had given her. From Anni's perspective, Rachel "is grateful because [...] she has lost many of them" (Anni, critical incident 21). Anni told Rachel to keep it safe in her pocket this time.

A third category was related to classroom routines $(\mathrm{f}=4)$, which were followed either by the teacher or a student in maintaining daily classroom habits. One of the incidents experienced by Matti took place when he was using the class projector. He posed a question to the whole group, and several students started to shout the answer. Matti then hushed them and said, "Raise your hand. Thank you", and the students followed his instruction. According to Matti, this situation conveyed the message, "When you are listening and behaving as I have instructed, it makes me feel good" (Matti, critical incident 10).

Finally, incidents in the self-sufficiency category $(\mathrm{f}=3)$ alluded to feelings, memories and efforts that teachers identified as being the rationales for their grateful feelings. For instance, Matti experienced a moment of gratitude when he could acknowledge his own professional history, the reason being that this incident was linked to his personal story of being "a young teacher" (Matti, critical incident 8).

\subsection{Teachers' Perceptions of Expressions of Gratitude in the Classroom Environment}

Among the 26 critical incidents, 33 expressions were identified as manifestations of gratefulness (Table 4). The results are shown using Baumgarten-Tramer's (1938) framework. Gratitude was expressed verbally $(\mathrm{f}=6)$ only by the teachers. For example, at the end of one lesson, Rachel walked towards Anni and gave her a little paper gift while others watched. Anni bowed as she received the present and seemed surprised by the gift. She expressed her gratitude by saying, "Wow, thank you very much! Is it for me?" Rachel nodded and Anni then invited the girl to leave the present on her desk (Anni, critical incident 25).

Table 4. Expressions of gratitude in a classroom environment

\begin{tabular}{cccc}
\hline Categories & $\begin{array}{c}\text { Students } \\
f=24\end{array}$ & $\begin{array}{c}\text { Teachers } \\
f=9\end{array}$ & $\begin{array}{c}\text { In total } \\
f=33\end{array}$ \\
\hline Verbal (V) & 0 & 6 & 6 \\
Concrete (CT) & 17 & 2 & 19 \\
Connective (CV) & 6 & 2 & 8 \\
\hline
\end{tabular}


Teachers perceived concrete manners $(\mathrm{f}=19)$, in other words, active demonstrations of appreciativeness, as the most typical way in which students express their gratitude. In the classroom studied here, Owen walked towards Matti's desk and waited there for the other students to leave. The boy leaned on the desk and asked Matti for a yellow pencil. Matti nodded, went to pick up a yellow pencil, and gave it to Owen. The boy went back to his place while staring at the pencil and smiling for several seconds (Matti, critical moment 1). Concrete ways to express gratitude were smiling, giving a hug, giving a teacher a paper gift or drawing, as well as a student's special engagement in finishing the task at hand.

Connective $(\mathrm{f}=8)$ instances of gratefulness occurred, for example, when Matti supervised students' work by walking around their desks. As he began to help one student, two more students on the same row asked for help by shouting his name or raising their hands. In response, Matti went to each pupil and helped with each of their tasks. About this incident Matti commented, "They trust me and can ask for help" (Matti, critical moment 13), which was his way of expressing gratitude for having good relationships with his students. Another example of this category took place in Anni's lesson, when most of the students seemed to be doing their own task. Arthur started to wander around the classroom and talk with his classmates. Anni noticed and gently led Arthur back to his place so he could continue his task. Anni reported that during the lesson she had to give another activity to Arthur because he had forgotten his math book at home. Moreover, the boy was going through the first grade for the second time. According to Anni, Arthur expressed his gratitude by doing the task that she gave him. At the same time, the student had a gentle look on his face when he looked at the teacher, indicating a connection with Anni who seemed to recognise particular characteristics of this boy's personal story to help him accomplish a task. In these kinds of cases, students with academic challenges need special attention to be able to finish their assignments.

\section{Discussion}

Gratitude as a scientific topic is growing in interest and should be explored in different contexts in order to increase understanding of this concept. The present study investigated two Finnish teachers' perceptions of gratitude in a classroom context, and particularly what the students and teachers were grateful for and how this was expressed. As an exploratory investigation, the present article contributes important insights to the discussion on gratitude and its occurrence within educational environments.

The first research question was "What are teachers" perceptions of the reasons for gratitude in classroom contexts?" Based on the results, teachers perceived that teacher-student relationships were an important trigger for gratitude in the classroom environment. On the one hand, this result supports findings by Gordon et al. (2004), who found that students most often mentioned their teachers as the reason for feeling appreciative. Along with friends, teachers help children to construct a sense of belonging (Gordon et al., 2004), which might provide them with important tools during their daily life at school. On the other hand, this result could be related to the importance of the teacher's ability to 
build this relationship, which seems crucial for pedagogical well-being as well as for improved learning outcomes (Soini, Pyhältö, \& Pietarinen, 2010). Studentteacher relationships, including trustful interactions, positive feedback and attention, were a consistent reason for students to be grateful. This finding illustrates that teachers play an important role in creating an environment in which students feel safe to learn (Howells, 2014) and are encouraged to engage in learning (Liauw et al., 2018).

The present study also revealed that students may have experienced gratitude to their teachers when structure and specific routines were established in the classroom. This might be related to Howells and Cumming (2012) idea of gratitude as a practice whereby individuals act on their appreciative feelings by thanking or greeting teachers or by acknowledging the experiences. However, the present study illustrates the significance of simple routines for students and their daily life at school. Moreover, this paper assumes that teachers' and students' actions and perceptions are related to their worldviews of social relationships, since their beliefs are put into operation in school (van der Kooij et al., 2013).

Although in this study verbal gratitude was expressed only by teachers, this is in line with the idea that teachers serve as role models (Liauw et al., 2018), and their continuous efforts to foster gratitude and focus on it might help develop gratitude (Bono \& Froh, 2009). As for material benefits, it seemed that teachers played a role in the day-to-day activities of the classroom environment. Material benefits are related to concrete gratitude, as pointed out by Baumgarten-Tramer (1938), since the individual wants to give an object in return for the benefit. Furthermore, the above statement works as an important link to the results of the second research question, namely, "How is gratitude expressed in classroom contexts?" The present study shows that teachers perceived students as expressing gratitude largely in a concrete manner in the classroom. This finding is in line with previous studies that have shown how smaller children express gratitude in a concrete way more frequently than older children (Freitas et al., 2011; Baumgarten-Tramer, 1938). Although children might begin to experience and understand gratitude as early as the age of five (Nelson et al., 2013), it is not until decentration processes take place, along with an ability to empathize, which typically arise during early adolescence, that children experience more complex gratitude (Froh, Bono, \& Emmons, 2010; Gordon et al., 2004). Thus, we speculate that finalistic gratitude was not observed in this study because of its complexity and thus has been reported only in young adolescents (see Baumgarten-Tramer, 1938; Freitas et al., 2011).

The present study furthermore sheds light on connective gratitude and provides evidence to show that complex gratitude does take place in the classroom environment. Some first-grade students were reported as having experienced connective gratitude when the teacher knew details of the child's personal story. This has been suggested previously as a kind of gratitude based on affective bonds and will not necessarily follow progressive psychological processes, but rather a more qualitative development (Baumgarten-Tramer, 1938; Freitas et al., 2011). Based on the presented findings, we suggest that this type of gratitude 
involves a long process that takes into account individuals' personal life experiences and backgrounds, not only the affective scope. However, this subject still needs to be addressed in future research.

The results of this exploratory study show that gratitude might occur in classroom interactions that have teacher-student relationships as their main rationales, but also where there are classroom routines and material benefits. Its expressions might vary from connective to verbal, but in the present study they occurred mostly in a concrete way.

These findings contribute to the ongoing debate about gratitude in the school environment and invite future researchers to use qualitative methods to investigate this topic. The expressions of gratitude in a natural school setting, specifically in a primary school context, constitute a meaningful effort and are an explicit novelty, given that gratitude has not been scientifically studied in these kinds of settings. The study fulfils the quest to understand gratitude in a school context and provides evidence of how gratitude occurs among small children and teachers. Moreover, teachers can draw important points from this study in reflecting on Matti's and Anni's practices. Daily life in the context of first-grade students might have important consequences for the development of strong and complex feelings of gratitude in the future.

The present study has important limitations that should be taken into consideration in analysing its results. The first limitation is that, during the data collection, the main researcher was not a fluent Finnish speaker, which could have biased some of the results, although a method triangulation with a native speaker and the teacher was carried out. A second limitation was that the main researcher did not belong to either the Finnish culture or the school culture at the time the data were gathered. This could have made some of the participants uncomfortable, preventing them from expressing themselves naturally. However, both participating teachers were experienced professionals, who prepared the students and their parents for the research day, and the teachers also knew at the beginning of the research that the work would be conducted bilingually. A third limitation is the number of classes investigated: these included only those in maths. To improve validity of the study, multiple methods were utilized in data gathering and analysis. Nevertheless, future studies are needed to cover longer periods in classrooms and lessons on different subjects. Also, students' viewpoints need to be taken into account to provide an even deeper understanding of gratitude in classroom interactions.

\section{Acknowledgements}

The present article is based on the data and ideas from the thesis submitted in fulfilment of Master's degree in Education, University of Jyväskylä. The corresponding author would like to thank the second and third authors for the discussions and various viewpoints expressed during their seminars. 


\section{References}

Baumgarten-Tramer, F. (1938). 'Gratefulness' in Children and Young People. Pedagogical Seminary and Journal of Genetic Psychology 53, 53-66.

Bono, G., \& Froh, J. (2009). Gratitude in School. In R. Gilman, S. Huebner, \& M. Furlong (Eds.) Handbook of Positive Psychology in Schools (pp. 77-88). New York: Routledge.

Calderhead, J. (1981). Stimulated Recall: A Method for Research on Teaching. British Journal of Educational Psychology 51(2), 211-217.

Eisenstein, M., \& Bodman, J. (1993). Expressing Gratitude in American English. In G. Kasper, \& S. Blum-Kulka (Eds.) Interlanguage Pragmatics (pp. 64-81). Oxford University Press. Retrieved from EBSCO database.

Elo, S., \& Kyngäs, H. (2008). The Qualitative Content Analysis Process. Journal of Advanced Nursing 62(1), 107-115. doi:10.1111/j.1365-2648.2007.04569.x.

Emmons, R. (2004). The Psychology of Gratitude. an Introduction. In R. Emmons, \& M. McCullough (Eds.) The Psychology of Gratitude (pp. 3-16) US: Oxford University Press.

Emmons, R., \& Shelton, C. (2005). Gratitude and the science of positive psychology. In C. R. Synder, \& S. J. Lopez (Eds.) Handbook of positive psychology (pp. 459-471). New York: Oxford University Press.

Finnish National Board of Education (2016). National Core Curriculum for the Basic Education. Helsinki: Next Print Oy.

Freitas, L., Pieta, M. A., \& Tudge, J. R. (2011). Beyond Politeness: The Expression of Gratitude in Children and Adolescents. Psicologia: Reflexão E Crítica 24(4), 757764. doi:10.1590/S0102-79722011000400016.

Froh, J., Bono, G., \& Emmons, R. (2010). Being Grateful is Beyond Good Manners: Gratitude and Motivation to Contribute to Society among Early Adolescents. Motivation and Emotion 34(2), 144-157. doi:10.1007/s11031-010-9163-z.

Froh, J., Sefick, W., \& Emmons, R. (2008). Counting Blessings in Early Adolescents: An Experimental Study of Gratitude and Subjective Well-Being. Journal of School Psychology 46(2), 213-233. doi:10.1016/j.jsp.2007.03.005.

Gass, S., \& Mackey, A. (2000). Stimulated Recall Methodology in Second Language Research. New Jersey: Lawrence Erlbaum Associates, Inc., Publishers.

Gordon, A. K., Musher-Eizenman, D., Holub, S., \& Dalrymple, J. (2004). What are Children Thankful for? an Archival Analysis of Gratitude before and After the Attacks of September 11. Journal of Applied Developmental Psychology 25(5), 541553. doi:10.1016/j.appdev.2004.08.004.

Graneheim, U., Lindgren, B., \& Lundman, B. (2017). Methodological Challenges in Qualitative Content Analysis: A Discussion Paper. Nurse Education Today 56, 2934. doi:10.1016/j.nedt.2017.06.002.

Gulliford, L., Morgan, B., \& Kristjánsson, K. (2013). Recent Work on the Concept of Gratitude in Philosophy and Psychology. The Journal of Value Inquiry 47(3), 285317. doi:10.1007/s10790-013-9387-8.

Hanhimäki, E., \& Tirri, K. (2009). Education for ethically sensitive teaching in critical incidents at school. The Journal of Education for Teaching 35(2), 107-121. doi:10.1080/02607470902770880.

Harpham, E. (2004). "Gratitude in the History of Ideas." In R. Emmons, \& M. McCullough (Eds.) The Psychology of Gratitude (pp. 19-36) US: Oxford University Press. 
Howells, K. (2014). An Exploration of the Role of Gratitude in Enhancing Teacherstudent Relationships. Teaching and Teacher Education 42, 58-67. doi:10.1016/j.tate.2014.04.004.

Howells, K., \& Cumming, J. (2012). Exploring the Role of Gratitude in the Professional Experience of Pre-Service Teachers. Teaching Education 23(1), 71-88. doi:10.1080/10476210.2011.638370.

Klein, M. (1988). Envy and Gratitude. In M. Klein (Ed.) Envy and Gratitude and Other Works, 1946-1963 (pp. 176-235). London: Virago Press.

Koltko-Rivera, M. (2004). The psychology of worldviews. Review of General Psychology 8(1), 3-58. doi:10.1037/1089-2680.8.1.3.

Liauw, I., Baelen, R., Borah, R. F., Yu, A., \& Colby, A. (2018). Gratitude for Teachers as a Psychological Resource for Early Adolescents: A Mixed-Methods Study. Journal of Moral Education, 1-18. doi:10.1080/03057240.2017.1415872.

Lyle, J. (2003). Stimulated Recall: A Report on its use in Naturalistic Research. British Educational Research Journal 29(6), 861-878. doi:10.1080/0141192032000137349.

McAdams D., \& Bauer, J. (2004). Gratitude in Modern Life. It's Manifestations and Development. In R. Emmons, \& M. McCullough (Eds.) The Psychology of Gratitude (pp. 81-99) US: Oxford University Press.

McCullough, M., Emmons, R., \& Tsang, J. (2002). The Grateful Disposition: A Conceptual and Empirical Topography." Journal of Personality and Social Psychology 82(1), 112-127. doi:10.1037//0022-3514.82.1.112.

Morgan, B., Gulliford, L., \& Kristjánsson, K. (2017). A New Approach to Measuring Moral Virtues: the Multi-Component Gratitude Measure. Personality and Individual Differences 107, 179-189.

Nelson, J., Freitas, L., O'Brien, M., Calkins, S., Leerkes, E., \& Marcovitch, S. (2013). Preschool-Aged Children's Understanding of Gratitude: Relations with Emotion and Mental State Knowledge. The British Journal of Developmental Psychology 31(Pt 1) 42-56. doi:10.1111/j.2044-835X.2012.02077.x.

Piaget J. (1995). Sociological Studies. New York: Routledge.

Soini, T., Pyhältö, K., \& Pietarinen J. (2010). Pedagogical Well-being: Reflecting Learning and Well-being in Teachers' Work. Teachers and Teaching 16(6), 735-751. doi:10.1080/13540602.2010.517690.

Tirri, K. (2010). “Teachers' values underlying their professional ethics." In T. Lovat et al. (Eds) International Handbook on Values Education and Student Well-Being (pp. 153163). New York: Springer.

Tirri, K. (2011). "Holistic School Pedagogy and Values: Finnish Teachers' and Students' Perspectives." International Journal of Educational Research 50(3), 159-165.

Tirri, K. (2014). "The Last 40 Years in Finnish Teacher Education." Journal of Education for Teaching 40(5), 1-10.

Tirri, K. (2016). Holistic perspectives on gifted education for the 21st century. In D. Ambrose, \& R. J. Sternberg (Eds.) Giftedness and Talent in the 21st Century (pp. 101-110). Rotterdam, the Netherlands: Sense Publishers.

Tirri, K., Husu, J., \& Kansanen, P. (1999). The epistemological stance between the knower and the known. Teaching and Teacher Education 15, 911-922.

Trade Union of Education in Finland (2010). Code of ethics for Finnish teachers. Helsinki: Trade Union of Education in Finland.

Tudge, J. (2008). The Everyday Lives of Young Children: Culture, Class, and Child Rearing in Diverse Societies. New York: Cambridge University Press.

Tudge, J., Freitas, L., \& O’Brien, L. (2015). The Virtue of Gratitude: A Developmental and Cultural Approach. Human development 58, 281-300. doi:10.1159/000444308. 
van der Kooij, J.C., de Ruyter, D., \& Miedema, S. (2013). "Worldview": the Meaning of the Concept and the Impact on Religious Education, Religious Education: The official journal of the Religious Education Association, 108(2), 210-228, doi:10.1080/00344087.2013.767685.

White, P. (1999). Gratitude, Citizenship and Education. Studies in Philosophy and Education, 18(1), 43-52. doi:1005183220317.

Wood, A., Maltby J., Stewart N., \& Joseph, S. (2008). Conceptualizing Gratitude and Appreciation as a Unitary Personal Trait. Personality and Individual Differences 44, 621-632. 